\title{
Matrilineage differentiation of the genus Tetragonisca using mitochondrial DNA markers and the polymerase chain reaction- restriction fragment length polymorphism technique
}

\author{
S.A. Santos ${ }^{1}$, A.R. Bronzato ${ }^{1}$, B.M.T. Moreira ${ }^{1}$, K.F. Araujo', L. Ronqui ${ }^{2}$, \\ C.A. Mangolin' ${ }^{1}$, V.A.A. Toledo ${ }^{2}$ and M.C.C. Ruvolo-Takasusuki ${ }^{1}$ \\ 1Departamento Biotecnologia, Genética e Biologia Celular, \\ Universidade Estadual de Maringá, Maringá, PR, Brasil \\ 2Departamento de Zootecnia, Universidade Estadual de Maringá, Maringá, PR, Brasil \\ Corresponding author: M.C.C. Ruvolo-Takasusuki \\ E-mail: mccrtakasusuki@uem.br \\ Genet. Mol. Res. 14 (4): 12828-12840 (2015) \\ Received January 12, 2015 \\ Accepted July 14, 2015 \\ Published October 21, 2015 \\ DOI http://dx.doi.org/10.4238/2015.October.21.2
}

\begin{abstract}
The Meliponinae are important pollinators of plant species, and one of the most managed species is Tetragonisca angustula. Initially, two subspecies were identified in $T$. angustula: $T$. angustula angustula and $T$. angustula fiebrigi. Subsequently, T. a. fiebrigi was considered a species, based on the coloration of its mesepisternum. The objective of the present study was to obtain genetic markers that could differentiate the two species by amplifying regions of mitochondrial DNA and conducting polymerase chain reaction-restriction fragment length polymorphism analysis. Worker bees were collected in three Brazilian states: Paraná (Maringá, Altônia, and Foz do Iguaçu), São Paulo (Dracena, São Carlos, and Santa Cruz do Rio Pardo), and Rondônia (Ariquemes). Ten pairs of insect heterologous primers were tested and four were used (primer pair 1, ND2 and COI;
\end{abstract}


primer pair 2, COI; primer pair 8, $16 \mathrm{~S}$ and 12S; and primer pair 9, COII). For the restriction analysis, 13 enzymes were tested: EcoRI, EcoRV, HindlII, Hinfl, Rsal, Pstl, Xbal, Haelll, Clal, Xhol, Bglll, Pvull, and Scal. Markers were obtained (primer pair 8 cleaved with EcoRV and Xbal and primer pair 9 cleaved with Haelll, Rsal, and Xbal) that enabled matrilineage identification in the nests studied, which confirmed that hybridization could occur between both Tetragonisca species. The beginning of speciation was probably recent, and secondary contact has resulted in crosses between $T$. angustula females and T. fiebrigi males. Because of this hybridization, it would be appropriate to consider them as two subspecies of $T$. angustula.

Key words: Stingless bee; Heterologous primer; PCR-RFLP; Bayesian analysis

\section{INTRODUCTION}

The Meliponinae (Hymenoptera, Apidae) are stingless bees (Michener, 2000) that occur in South and Central America, Asia, the Pacific Islands, Australia, New Guinea, and Africa. They are of great economic and cultural importance as pollinators, maintain the ecological balance of most terrestrial ecosystems (Kerr et al., 1987; Camargo and Pedro, 1992; Carvalho and Marchini, 1999), and are important honey producers.In Brazil, approximately 400 species of stingless bees are found.Tetragonisca angustula is one of the most managed species, and is distributed from Argentina to southern Mexico (Nogueira-Neto, 1997). This group of stingless bees is the most common in the Neotropics, and adapts quite easily to different nesting conditions (Castanheira and Contel, 2005), including urban environments. Bees of the genus Tetragonisca are particularly important in north and northeast Brazil (Menezes-Pedro and Camargo, 2000), where the extraction of honey, wax, and resins is widespread (Sawaya et al., 2006).

Initially, Tetragonisca was divided into two subspecies: Tetragonisca angustula fiebrigi Schwarz and Tetragonisca angustula angustula Latreille. They differ in their geographical distributions; T. a. angustula is distributed from Mexico to Argentina, whereas T. a. fiebrigi is restricted to certain regions of southern Brazil (São Paulo, Paraná, and Santa Catarina) and parts of Argentina and Paraguay (Nogueira-Neto, 1997). However, there is controversy regarding the taxonomy of thesebees. Castanheira and Contel (2005) are of the opinion that Tetragonisca constitutes a species with two subspecies: T. a. fiebrigi and T. a. angustula, while Camargo and Pedro (2007) consider them two separate species, $T$. angustula and T. fiebrigi. The difference between these subspecies is morphological, and is the colorof a pigment found in the mesepisternum (Oliveira et al., 1995; Castanheira and Contel, 2005). In T. angustula the mesepisternum is black, and in T. fiebrigit is yellow. This variation in mesepisternum color is controlled by several genes, and crosses between these subspecies result in hybrids that exhibit mesepisterna with yellow or black spots (Oliveira et al., 1995; Castanheira and Contel, 2005).

Castanheira and Contel (1995) sought to identify differences between the subspecies by allelic variations in the hexokinase enzyme, and found a higher frequency of the allele Hk88 in bees with yellow mesepisterna, indicating that this allele may have originated in $T$. fiebrigi.

Random Amplified Polymorphic DNA (RAPD) markers have revealedtwo distinct groups according to their geographical distributions (Oliveira et al., 2004); however, they did not separate 
them as species. Baitala et al. (2006) also used RAPD markers to separate the species, and found that the separate populations were highly polymorphic. Koling and Moretto (2010) found differences in the restriction patterns of mitochondrial DNA (mtDNA) in ATPase regions 8, 6, and COIII of bees collected in Santa Catarina State, Brazil, which resulted in their classification as subspecies. Stuchi et al. (2012) conducted an esterase biochemical characterization (as described by Camargo and Pedro, 2007) that suggested that $T$. angustula and T. fiebrigiare different species, because esterases 1, 2, and 4 were found in T. fiebrigi workers and esterases 3 and 4 were found in T. angustula workers. Francisco et al. (2014) confirmed the existence of hybrids between Tetragonisca by sequencing their mtDNA regions and conducting microsatellite analysis, and suggest that these bees are subspecies.

However, it remains unclear whether $T$. angustula can be taxonomically classified as two different species or subspecies. Therefore, the aim of this study was to find genetic markers that could differentiate these species by amplifying mitochondrial DNA regions and conducting polymerase chain reaction-restriction fragment length polymorphism (PCR-RFLP) analysis.

\section{MATERIAL AND METHODS}

\section{Biological material}

Workers from 30 nests were used, which were collected from three Brazilian states: Paraná (five nests from Maringá, four from Altônia, and one from Foz do lguaçu), São Paulo (five nests from Dracena, five from San Carlos, and five from Santa Cruz Rio Pardo), and Rondônia (five nests from Porto Velho) (Figure 1). After collection, the bees were sacrificed by freezing and kept in a freezer at $-20^{\circ} \mathrm{C}$ until DNA isolation.

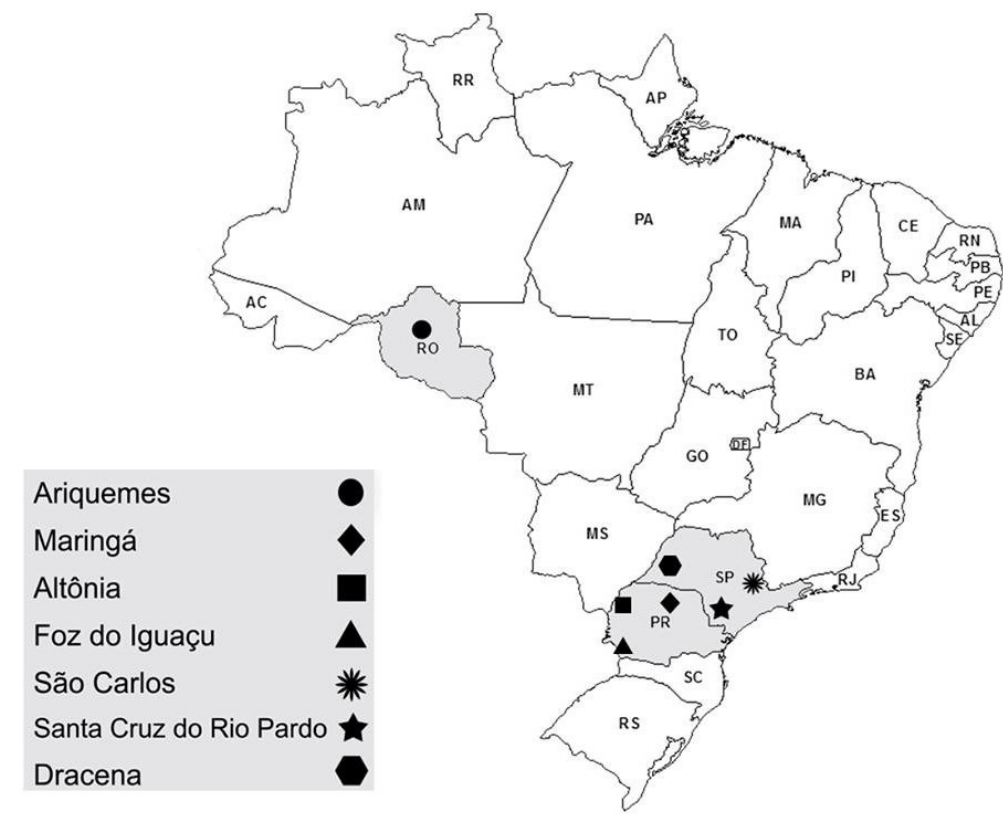

Figure 1. Sampling sites in the Brazilian states of Paraná (PR), São Paulo (SP), and Rondônia (RO). 


\section{Morphological identification}

Two workers per collected nest were morphologically analyzed usinga stereoscopic microscope Karl Zeiss (Germany), based on the color of the mesepisternum (Castanheira and Contel, 1995). The bees were classified as follows: black mesepisternum, T. angustula; yellow mesepisternum, T. fiebrigi; and intermediate mesepisternum, hybrid between both species.

\section{Genomic DNAextraction}

Total DNA was extracted from the thoraces of five workers per nest, totaling 150 samples. Theextraction method used was the same as that described by Yu et al. (1993), except that the DNA was extractedfrom the thorax rather than the head and was incubated for $1 \mathrm{~h}$ in a water bath instead of overnight.

\section{DNA precipitation}

The integrity and quantification of the DNA were analyzed on $0.8 \%$ agarose gel in $1 \mathrm{X}$ TAE buffer (Tris, acetic acid, and EDTA; pH 8.0). The amount of DNA present in each sample was estimated by comparison with known and graded concentrations of standard DNA ( $\lambda$ phago). The gels were stained in an ethidium bromide bath $(0.5 \mathrm{mg} / \mathrm{mL})$ and the DNA fragments were visualized under ultraviolet light.Imageswerecaptured using an L-HEPix photo documentation system.

\section{PCR-RFLP analysis}

For the mtDNA amplification and analysis of Tetragonisca nests, 10 heterologous primer pairs as described by Hall and Smith (1991) and Simon et al. (1994) were used, according to the methodology employed by Francisco et al. (2001) (Table 1). The PCRs were conducted using DNA from five workers per nest.

\begin{tabular}{|c|c|c|c|c|c|}
\hline Primer & Name & Sequence $\left(5^{\prime} \rightarrow 3^{\prime}\right)$ & Reference & Gene & Temperature $\left({ }^{\circ} \mathrm{C}\right)$ \\
\hline \multirow[t]{2}{*}{1} & $\mathrm{mtD} 2$ & GCTAAATAAGCTAACAGGTTCAT & (Simon et al., 1994) & $\mathrm{ND} 2, \mathrm{COI}$ & 45 \\
\hline & mtD9 & CCCGGTAAAATTAAAATATAAACTTC & & & \\
\hline \multirow[t]{2}{*}{2} & $\mathrm{mtD7}$ & GGATCACCTGATATAGCATTCCC & (Simon et al., 1994) & $\mathrm{COI}$ & 46 \\
\hline & COI-IIR & GATCAATATCATTGATGACC & (Hall and Smith, 1991) & & \\
\hline \multirow[t]{2}{*}{3} & mtD19 & GAAATTTGTGGAGCAAATCATAG & (Simon et al., 1994) & ATPases $(8,6)$, COIII & 47 \\
\hline & $\mathrm{mtD} 22$ & TCAACAAAGTGTCAGTATCA & & & \\
\hline \multirow[t]{2}{*}{4} & $5612 R$ & GAAATTAATATAACATGACCACC & (Francisco et al., 2001) & COIII, ND3 & 47 \\
\hline & tPheF & GCGTAATATTGAAAATATTAATGA & & & \\
\hline \multirow[t]{2}{*}{5} & $\mathrm{mtD} 24$ & GGAGCTTCAACATGAGCTTT & (Simon et al., 1994) & ND4, ND6, CytB & 44 \\
\hline & $\mathrm{mtD} 28$ & ATTACACCTCCTAATTTATTAGGAAT & & & \\
\hline \multirow[t]{2}{*}{6} & $\mathrm{mtD} 26$ & TATGTACTACCATGAGGACAAATATC & (Simon et al., 1994) & CytB, ND1 & 45 \\
\hline & $\mathrm{mtD} 30$ & GTAGCATTTTTAACTTTATTAGAACG & & & \\
\hline \multirow[t]{2}{*}{7} & Mel 3 & TAAAGTTAAAAAAGCAACTC & (Francisco et al., 2001) & $16 S$ & 44 \\
\hline & $16 S F$ & CACCTGTTTATCAAAAACATGTCC & (Hall and Smith, 1991) & & \\
\hline \multirow[t]{2}{*}{8} & $16 S R$ & CGTCGATTTGAACTCAAATCATG & (Hall and Smith, 1991) & $16 \mathrm{~S}, 12 \mathrm{~S}$ & 45 \\
\hline & $\mathrm{mtD} 36$ & AAACTAGGATTAGATACCCTATTAT & (Simon et al., 1994) & & \\
\hline \multirow[t]{2}{*}{9} & MtD18 & CCACAAATTTCTGAACATTGACCA & (Simon et al., 1994) & coll & 47 \\
\hline & COI-IIF & TCTATACCACGACGTTATTC & (Hall and Smith, 1991) & & \\
\hline \multirow[t]{2}{*}{10} & Seq 18 & GAACTATCAATTTGATATTG & (Francisco et al., 2001) & ND4, ND5 & 46 \\
\hline & $8467 \mathrm{~F}$ & GGAATTTTTTTTTTGAATGAAA & & & \\
\hline
\end{tabular}


The amplification conditions were based on those described by Barni et al. (2007), with modifications to the annealing temperatures of the primers (Table 1). The reactions were conducted in a Veriti ${ }^{\mathrm{TM}}$ 384-well thermo cycler (Applied Biosystems). The amplification products were separated on $1 \%$ agarose gel at $60 \mathrm{~V}$ using a $0.5 \mathrm{X}$ TBE buffer (Tris-borate EDTA, pH 8.0) and stained in an ethidium bromide bath $(0.5 \mathrm{mg} / \mathrm{mL})$. The amplification fragments were visualized under ultraviolet light and imageswere captured byL-Pix HE. A DNA molecular weight marker (100bp DNA ladder, Invitrogen) was used to determine the sizes of the generated fragments.

For the restriction analysis, amplified mtDNA fragments were digested for $12 \mathrm{~h}$ with the following enzymes: EcoRI, EcoRV, Hindlll, Hinfl, Rsal, Pstl, Xbal, Haelll, Clal, Xhol, Bg/ll, Pvull, and Scal (Invitrogen). Each cleavage reaction contained $3 \mu \mathrm{L}$ PCR, $3 \mathrm{U}$ restriction enzyme, enzyme $1 \mathrm{X}$ buffer, and 14.7 $\mu \mathrm{L}$ Milli- ${ }^{\circledR}$ water, totaling $20 \mu \mathrm{L}$. The digestion results were analyzed on agarose gel and subjected to the same conditions asthe amplification products.

\section{Data analysis}

Analysis of the molecular data involved the interpretation of the mitochondrial DNA fragments that were cleaved with restriction enzymes. Genetic differentiation coefficients were calculated using POPGENE 1.32 software (Yeh et al., 1999), and a dendrogram was constructed using these data (Nei, 1978). GenAlEx 6.5 software (Peakall and Smouse, 2006) was used to conduct an analysis of molecular variance (AMOVA). To estimate the number of genetic groups within the data, a Bayesian estimation was performed using the STRUCTURE program version 2.3.4 (Pritchard et al., 2000). Burn-in was set at 3000 repetitions and Markov Chain Monte Carlo at 30,000 repetitions. The number of interactions was set at 10 . The estimate of the real number of populations according to Evanno et al. (2005) may be performed employing the statistical delta $K=\operatorname{Ln}(P(X / K))$ between successive values of $K$ (number of populations) and $X=$ probability observing the data. The value of $\mathrm{K}$ used was one that presented the highest delta $\mathrm{K}$.

\section{RESULTS}

\section{Morphological identification}

The results of the morphological identificationare shown in Table 2. Individuals from nests in Ariquemes and Santa Cruz do Rio Pardo (São Paulo) were all T. angustula, and those from Dracena (São Paulo) and São Carlos (São Paulo) included both T. angustula and T. fiebrigi. Both species were identified in Paraná state, and a hybrid with intermediate coloration was found in Altônia.

Table 2. Sampling sites and species identification according to morphological analysis.

\begin{tabular}{|c|c|c|c|c|c|c|c|}
\hline \multirow[t]{2}{*}{ City (State) } & \multicolumn{2}{|c|}{ Geographical coordinates } & \multicolumn{5}{|c|}{ Morphologically identified nests } \\
\hline & Latitude (S) & Longitude (W) & 1 & 2 & 3 & 4 & 5 \\
\hline Maringá (PR) & $23^{\circ} 25^{\prime} 38^{\prime \prime}$ & $51^{\circ} 56^{\prime} 15^{\prime \prime}$ & T.f & T.a & T.a & T.a & T.a \\
\hline Altônia (PR) & $23^{\circ} 52^{\prime} 28^{\prime \prime}$ & $53^{\circ} 54^{\prime} 06^{\prime \prime}$ & T.f & T.f & T.f & $\mathrm{H}$ & \\
\hline Foz do Iguaçu (PR) & $25^{\circ} 32^{\prime} 52^{\prime \prime}$ & $54^{\circ} 35^{\prime} 17^{\prime \prime}$ & T.f & & & & \\
\hline Santa Cruz do Rio Pardo (SP) & $22^{\circ} 53^{\prime} 56^{\prime \prime}$ & $49^{\circ} 37^{\prime} 57^{\prime \prime}$ & T.a & T.a & T.a & T.a & T.a \\
\hline Dracena (SP) & $21^{\circ} 28^{\prime} 57^{\prime \prime}$ & $51^{\circ} 31^{\prime} 58^{\prime \prime}$ & T.a & T.f & T.f & T.f & T.f \\
\hline São Carlos (SP) & $22^{\circ} 01^{\prime \prime}$ & $47^{\circ} 54^{\prime \prime}$ & T.f & T.f & T.a & T.a & T.f \\
\hline Ariquemes (RO) & $09^{\circ} 54^{\prime} 48^{\prime \prime}$ & $63^{\circ} 02 ' 27^{\prime \prime}$ & T.a & T.a & T.a & T.a & T.a \\
\hline
\end{tabular}

T.f = Tetragonisca fiebrigi; $T . a=$ Tetragonisca angustula; $\mathrm{H}=$ hybrid. 


\section{Analysis of mitochondrial DNA regions using the PCR-RFLP technique}

Of the 10 primers tested, only four exhibited reproducible fragment patterns (primers 1, 2, 8 , and 9) and were used in the analyses (Table 1).

\section{Primer pair 1}

mtDNA amplification with primer pair 1 revealed two fragments, one that was approximately $2400 \mathrm{bp}$ long and the other $900 \mathrm{bp}$ long. The smallest fragment (900 bp) exhibited one polymorphism that occurred during the amplification of T. angustula samples from Porto Velho (Rondônia); the amplification of this fragment occurred in all of the samples from the other areas. The detection of smaller fragments was verified intra-nest. The successful amplification of the 900-bp fragment occurred as follows: nest 1 (subjects 2, 4, and 5), nest 2 (subject 1), nest 3 (subjects 2 and 3 ), nest 4 (subjects 1 and 3 ), and nest 5 (subjects 4 and 5) (Figure 2).

The 2400-bp fragment was cleaved with the EcoRI enzyme, and samples from Altônia exhibited three different haplotypes (Figure 2). Cleaving the 2400-bp band resulted in haplotype 1, with 500- and 1900-bp fragments; haplotype 2, with 1800- and 600-bp fragments; and haplotype 3, which was from individuals that did not exhibit cleavage. Individuals from nest 1 in Altônia, nests 2, 3, 4, and 5 in Maringá, and from every nestin Dracena, São Carlos, and Santa Cruz do Rio Pardo were haplotype 1. Individuals from nest 1 in Maringá, nest 2 in Altônia, the hybrid nest, and those from Foz do Iguaçu were haplotype 2. Individuals from nest 3 in Altônia and from all of the nests in Porto Velho were haplotype 3.

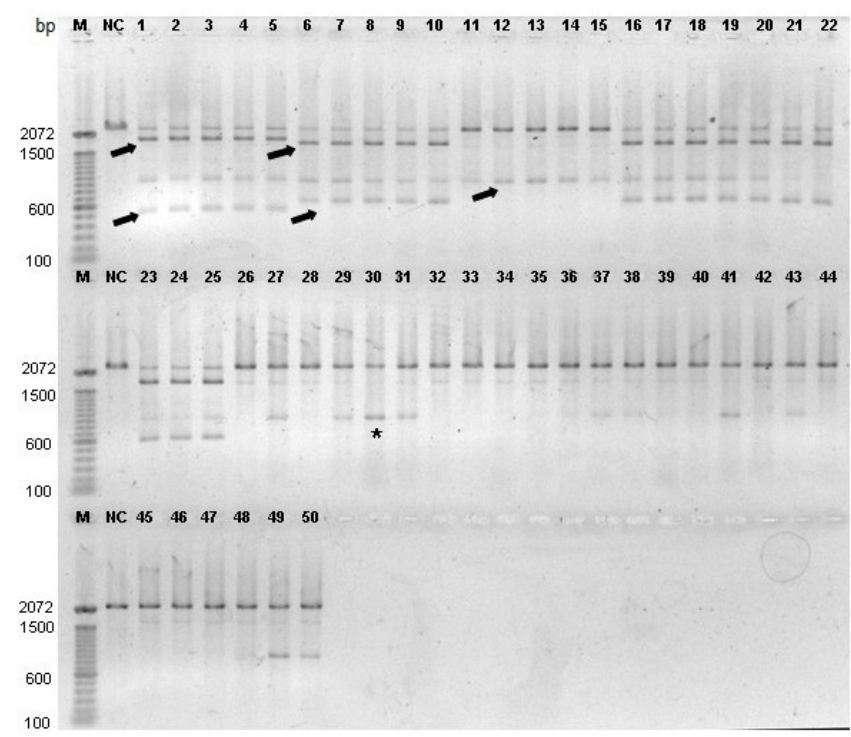

Figure 2. Cleaving profile using the EcoRI enzyme (white arrows) for the amplified region of primer pair 1 in Tetragonisca fiebrigi from Altônia and Foz do Iguaçu. Samples from Altônia: 1-5, nest 1 (haplotype 1); 6-10, nest 2 (haplotype 2); and 11-15, nest 3 (haplotype 3, no cleavage). Samples 16-20 correspond to the hybrid nest from Altônia; 20-25 to the T. fiebrigi nest from Foz do Iguaçu. Samples from Ariquemes: 26-30, nest 1; 31-35, nest 2; 36-40, nest 3; 41-45, nest 4; and 46-50, nest 5. Lane $M=100$-bp molecular weight marker (DNA ladder, Invitrogen); lane $N C=$ not cleaved; asterisk, 900-bp fragment. 
For the Haell enzyme, cleaving was observed only forthe 900-bp fragment, which resulted in two fragments, one that was approximately $600 \mathrm{bp}$ long and the other $300 \mathrm{bp}$ long. Similarly, the Hinfl enzyme exhibited the same cleavage pattern in both analyses, with no polymorphisms. Regarding the Rsal enzyme, cleaving resulted in 400- and 300-bp fragments, and no polymorphism was detected. The remaining region of the cleaved fragment was not identified.

\section{Primer pair 2}

Primer pair 2 amplified an 1850-bp fragment in both species. EcoRV digestion resulted in two fragments, one that was approximately $1000 \mathrm{bp}$ long and the other $850 \mathrm{bp}$ long. Cleaving with Hinfl resulted in three fragments $(900,400$, and 300 bp); it was not possible to estimate the size of the other fragments. Polymorphism was not observed in either analyses.

\section{Primer pair 8}

Primer pair 8 generated two fragments, one about $1850 \mathrm{bp}$ long and the other 350 bp long. The 1850-bp fragment was cleaved with EcoRV, Pstl, Rsal, and Xbal, where as the 350-bpfragment was only cleaved with Haelll. Cleaving the 1850-bp fragment with EcoRV resulted in two fragments, one that was approximately $950 \mathrm{bp}$ long and the other $900 \mathrm{bp}$ long. This region was cleaved in individuals from nest 1 in Altônia (Figure 3), from nests 2, 3, 4, and 5 in Maringá, and in all individuals from nests in Ariquemes, Santa Cruz do Rio Pardo, São Carlos, and Dracena. There was no cleaving in individuals from nest 1 in Maringá, Foz do Iguaçu, or from nests 2 and 3 in Altônia, or the hybrid (Figure 3).

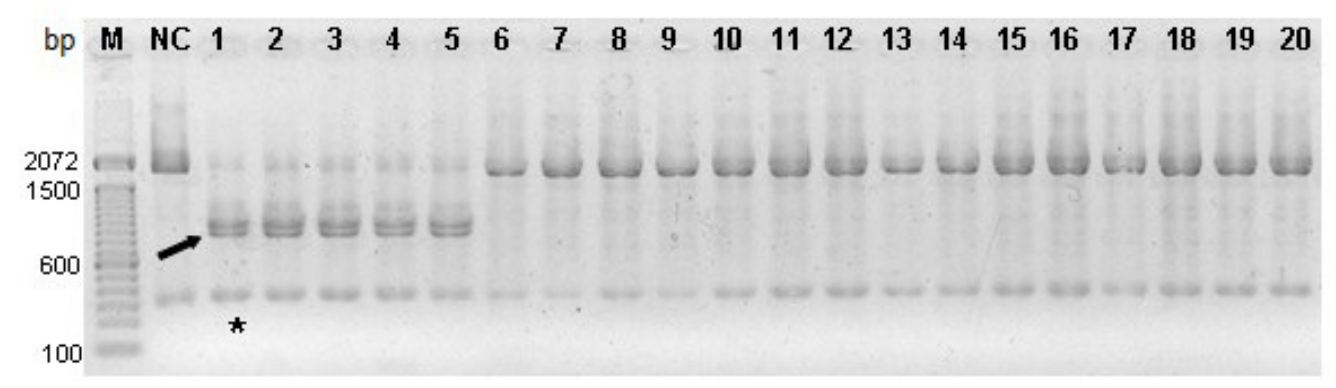

Figure 3. Cleaving profile using the EcoRV enzyme (white arrow) for the amplified region of primer pair 8 in Tetragonisca fiebrigi from Altônia. Samples 1-5, nest 1; 6-10, nest 2; 11-15, nest 3; and 16-20, the hybrid nest. Lane $M=100-b p$ molecular weight marker (DNA ladder, Invitrogen); lane NC = not cleaved; asterisk, 350-bp fragment.

Pstl cleaved the 1850-bp fragment into 1300- and 550-bp fragments, which did not exhibit anypolymorphisms. Rsal produced three fragments (700, 500, and $450 \mathrm{bp}$ ); it was not possible to detect polymorphisms in the remainder. Cleaving the 1850-bp fragment with Xbal revealed a polymorphism; two fragments were produced (1400 and $450 \mathrm{bp}$ ) withno cleavage. Cleavage was detected in two fragments (1400 and $450 \mathrm{bp}$ ) in samples from nest 1 in Maringá (Figure 4), Foz do Iguaçu, nests 2 and 3 from Altônia, and the hybrid. No restriction with Xbal was observed in samples from nest 1 in Altônia, nests 2, 3, 4, and 5 from Maringá, or in any of the samples from Ariquemes, Santa Cruz do Rio Pardo, São Carlos, or Dracena (Figure 4). 


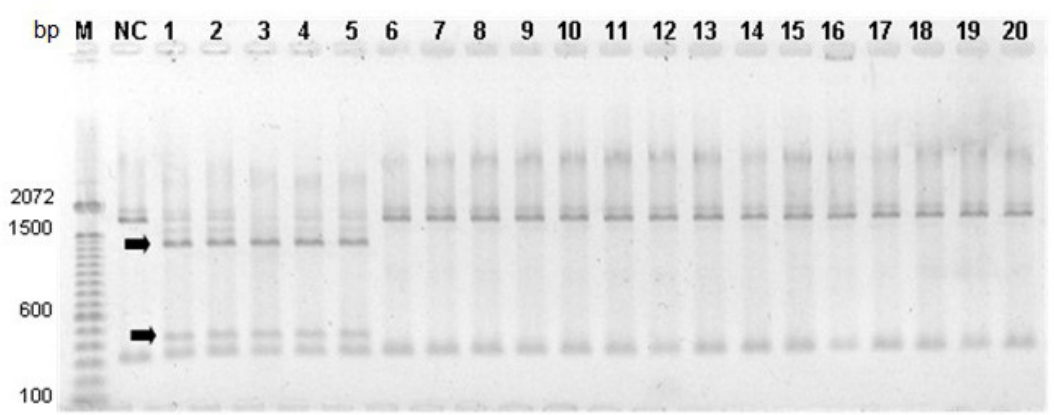

Figure 4. Cleaving profile using the Xbal enzyme for the amplified region of primer pair 8 in Tetragonisca fiebrigi (samples 1-5, nest 1) and $T$. angustula (samples 6-10, nest 2; 11-15, nest 3; and 16-20, nest 4) from Maringá. Lane $M$ $=100-\mathrm{bp}$ molecular weight marker (DNA ladder, Invitrogen); lane NC = not cleaved.

Haelll cleaved the 350 -bp fragment into two, one that was approximately $250 \mathrm{bp}$ long and the other 100 bp long; there were no polymorphisms.

\section{Primer pair 9}

DNA amplification using primer pair 9 revealed a polymorphism between the Tetragonisca species (Figure 5), because two amplification patterns were observed. The first pattern that matched samples of $T$. angustula resulted in a 1000-bp fragment, and the second resulted in 1100-bp and 1000-bp fragments. This pattern was found in samples from nest 1 in Maringá (Figure 5), nests 2 and 3 from Altônia (Figure 5), the hybrid nest, and the nest from Foz do Iguaçu. Clal cleaved the 1000-bp fragment into two fragments, one that was approximately $800 \mathrm{bp}$ long and the other 200 bp long. Restriction with Hinfl also generated two fragments, one that was approximately $600 \mathrm{bp}$ long and the other $400 \mathrm{bp}$ long. No polymorphisms were detected.

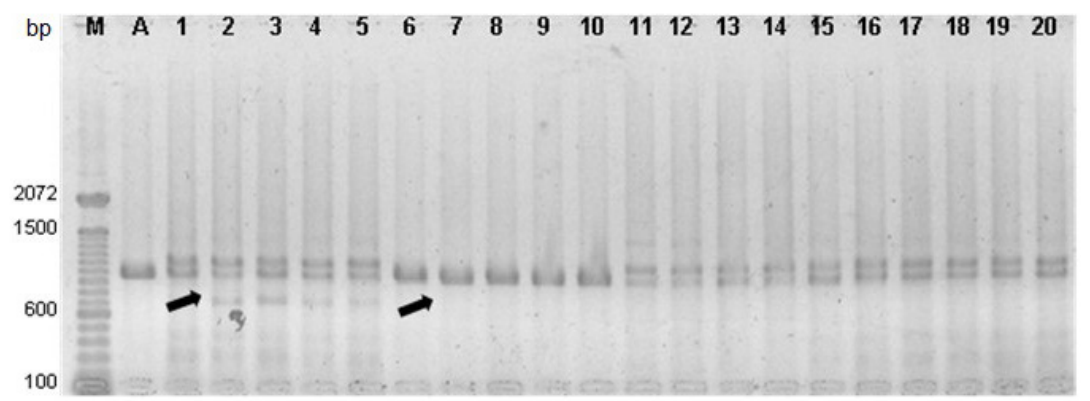

Figure 5. Amplification patterns obtained using primer pair 9in samples from Maringá (1-5, nest 1) and Altônia (samples 6-10, nest 1; 11-15, nest 2; and 16-20, nest 3). Lane $M=100$-bp molecular weight marker (DNA ladder, Invitrogen); lane $A=$ amplified DNA sample from Tetragonisca angustula.

mtDNA samples from nests in Dracena and São Carlos were identified as T. fiebrigi, and nest 1 in Altônia was identified as $T$. angustula when amplified with primer pair 9. Samples from nests that exhibited amplification patterns with two fragments during cleavage presented sites for Clal, Hinfl, Haelll, Rsal, and Xbal. These individualswere identified as T. fiebrigi, and were cleaved bythree different restriction enzymes that had no restriction sites for samples of $T$. angustula. 
Cleavage of the 1000-bp fragment with Clal resulted in 800- and 200-bp fragments that did not exhibit any polymorphisms. Although Hinfl cleaved the 1100-bp fragment, it was not possible to identify the resulting fragments. The 1000-bp fragment was cleaved to produce 600- and 400-bp fragments, without any polymorphisms observed. Haelll cleaved the 1100-bp fragment, but without any clearpattern. However, the 1000-bp fragment waspreserved and there was no polymorphism. Cleaving the 1100-bp fragment with Rsal resulted in no clearpattern, with the preservation of the 1000 -bp fragment. Cleaving with Xbal occurred only in the 1100-bp fragment, which resulted in an 800 -bp fragment; it was not possible to estimate the size of the remaining fragment(s). No polymorphism was detected.

The results of the Tetragonisca identification are presented in Table 3, and show that bees from nest 1 in Altônia and those from São Carlos and Dracena were identified as T. fiebrigi by morphology but were identified as having a $T$. angustula matrilineage by PCR-RFLP. After PCRRFLP marker analysis, the hybrid was identified as being from the T. fiebrigi matrilineage.

Table 3. Sampling sites and species identification according to morphological and mitochondrial DNA analysis.

\begin{tabular}{|c|c|c|c|c|c|c|c|c|c|c|}
\hline \multirow[t]{2}{*}{ City (State) } & \multicolumn{5}{|c|}{ Morphological identification per nest } & \multicolumn{5}{|c|}{ Identification based on mitochondrial DNA per nest } \\
\hline & 1 & 2 & 3 & 4 & 5 & 1 & 2 & 3 & 4 & 5 \\
\hline Maringá (PR) & T.f & T.a & T.a & T.a & T.a & T.f & T.a & T.a & T.a & T.a \\
\hline Altônia (PR) & T.f & T.f & T.f & $\mathrm{H}$ & & T.a & $T . f$ & T.f & T.f & \\
\hline Foz do Iguaçu (PR) & T.f & & & & & T.f & & & & \\
\hline Sta. Cruz do R. Pardo (SP) & T.a & T.a & T.a & T.a & T.a & T.a & T.a & T.a & T.a & T.a \\
\hline Dracena (SP) & T.a & T.f & T.f & T.f & T.f & T.a & T.a & T.a & T.a & T.a \\
\hline São Carlos (SP) & T.f & T.f & T.a & T.a & T.f & T.a & T.a & T.a & T.a & T.a \\
\hline Ariquemes (RO) & T.a & T.a & T.a & T.a & T.a & T.a & T.a & T.a & T.a & T.a \\
\hline
\end{tabular}

T.f, Tetragonisca fiebrigi; T.a, Tetragonisca angustula; $\mathrm{H}$, hybrid.

\section{Population genetics of $T$. angustula and T. fiebrigi}

The AMOVA showed that $83 \%$ of the variation occurredbetween populations and $17 \%$ occurred within populations, with an estimated value of $\Phi_{\mathrm{PT}}=0.834$ (significant at the 0.001 level), indicating that the populations are highly differentiated.

The Unweighted Pair Group Method with Arithmetic Mean (UPGMA) dendrogram, which was based on Nei's genetic distance (Nei, 1978) (Figure 6), shows two main groups: the first contained T. fiebrigi and the hybrid bees that were all collected in Paraná state, and the other contained Tetragonisca from São Paulo and Ariquemes (Rondônia).

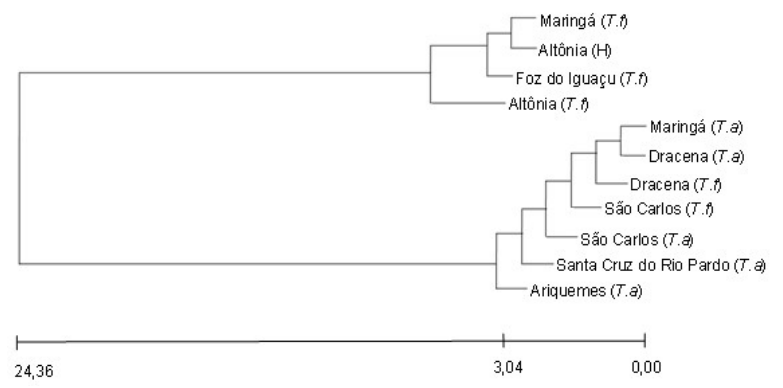

Figure 6. Dendrogram based on the arithmetic complement of Nei's genetic distance (Nei, 1978) using polymerase chain reaction-restriction fragment length polymorphism markers. Tetragonisca fiebrigi and $T$. angustula nests were grouped by the Un weighted Pair Group Method with Arithmetic Mean (UPGMA) method using PopGene 1.32 software. 
Bayesian inference analysis produceda similar result to that obtained using Nei's genetic distance (Nei, 1978) (Figure 7). We estimated the number of populations as $\mathrm{K}=6$, and confirmed that the populations $1,3,4$, and 5 , which corresponded to the $T$. fiebrigi collected in Paraná (Maringá, Altônia, and Foz do Iguaçu) are separated from the rest, except for nest 1 from Altônia, which exhibited T. angustula characteristics. Populations of T. fiebrigi from Dracena, São Carlos, and nest 1 in Altônia exhibited the same pattern of mtDNA markers as the remaining T. angustula, and it was impossible to distinguish between them.
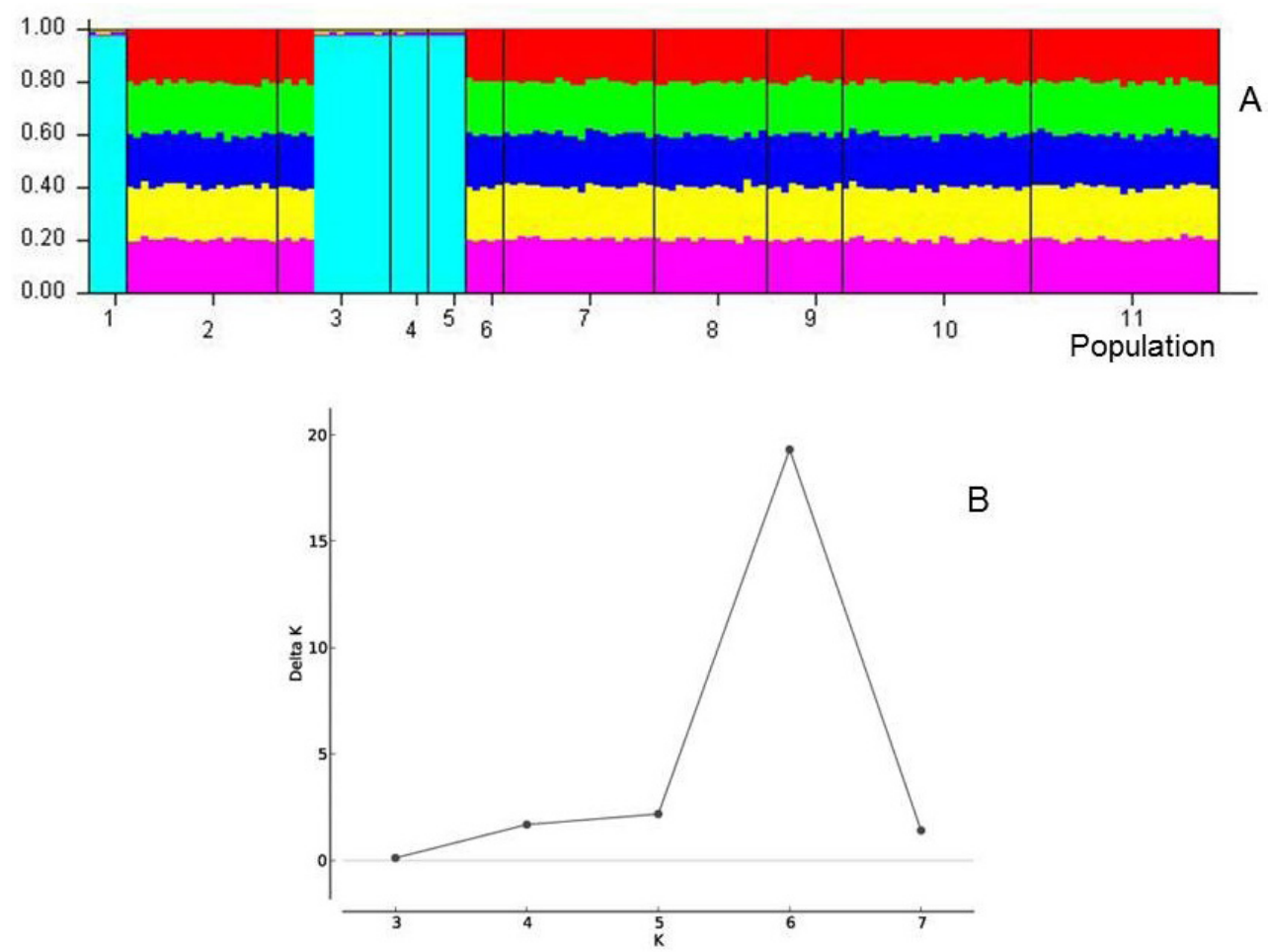

Figure 7. A. Bar graph obtained by Bayesian inference (Markov Chain Monte Carlo) with the number of populations estimated as $\mathrm{K}=6.1$, nest 1 from Maringá; 2, nests 2, 3, 4, and 5 from Maringá; 3, nests 1, 2, and 3 from Altônia; 4, hybrid nest from Altônia; 5, nest from Foz do Iguaçu; 6, nest 1 from Dracena; 7, nests 2, 3, 4, and 5 from Dracena; 8, nests 1 , 2, and 5 from São Carlos; 9, nests 3 and 4 from São Carlos; 10 and 11, all of the nests from Santa Cruz do Rio Pardo and Ariquemes, respectively. B. Estimate of the real number of populations using the method of Evanno et al. (2005).

\section{DISCUSSION}

In the study by Castanheira and Contel (2005), Tetragonisca angustula is divided into two subspecies that are morphologically distinguished by their mesepisternum coloration: Tetragonisca angustula angustula, which has a black mesepisternum, and Tetragonisca angustula fiebrigi, which has a yellow mesepisternum. Bees that exhibited variations in the color of their mesepisterna were also found, suggesting a cross between the species that would generate hybrids (Castanheira and Contel, 2005). Francisco et al. (2014) and Koling and Moretto (2010) observed these hybrid bees, 
and suggested that they could be subspecies.

In the present study, the mtDNA of $T$. angustula and $T$. fiebrigi were analyzed with four primerpairs and eight restriction enzymes. Amplification with primer pair 9 enabled us to verify that the initiator has the potential to be used in the identification of Tetragonisca bees.

Amplification of the mtDNA of both species usingprimer pair 9 and the cleavage patterns obtained with Haell, Rsal, and Xbal demonstrated that there were differences between morphological and mtDNA identification, because samples identified as $T$. fiebrigi collected in Altônia, São Carlos, and Dracena exhibited T. angustula mtDNA patterns (Table 3).

Primer pair 8 and cleaving with EcoRV and Xbal confirmed that there was a discrepancy between the morphological and molecular identification of the two species of Tetragonisca.

The polymorphism and identification inconsistencyin using molecular markers and morphological characteristics is probably due to speciation between the species, and a secondary contact before a complete separation between them had occurred. This secondary contact may have occurred due to human intervention, such as deforestation, the use of the bees by beekeepers due to their easy handling and honey production high prices on the market.

The microsatellite nuclear marker analysis of $T$. angustula and $T$. Fiebrigi specimens collected in São Carlos, Santa Cruz do Rio Pardo, Dracena, and Maringádid not allow us to separate them as species, butas populations (Bronzato, 2011). By analyzing them at the esterase isozyme level, it was possible to identify $T$. angustula and T. fiebrigi, as described in the study by Stuchi et al. (2012).A cytogenetic analysis of $T$. angustula and T. fiebrigi revealed that only $T$. fiebrigi has B chromosomes (Barth et al., 2011), allowing them to be separated as two distinct species. Diniz-Filho et al. (1998) identified morphological variation in T. angustula specimens collected in various regions of Brazil; body size varied in a north-south direction and wing size varied in an east-west direction.

Traditionally, the identification of $T$. angustula is based on mesepisternum color; however, natural variability within the species can lead to false identifications. Nests 2, 3, 4, and 5 from Dracena, nests 1, 2, and 5 from São Carlos, and nest 1 from Altônia were morphologically identified as T. fiebrigi; however, PCR-RFLP marker-based analysis revealed that they had similar matrilineal patterns as $T$. angustula bees, suggesting that crosses may have occurred between $T$. angustula females and T. fiebrigi males. Bees from the nest in Altônia that were identified as hybrids exhibited similar patterns to T. fiebrigi bees; therefore, the matrilineage source was T. Fiebrigi bees (Table 3). This confirmed that PCR-RFLP markers could be used for the identification of matrilineages.

Francisco et al. (2014) conducted a study on T. angustula and T. fiebrigi using microsatellite markers and mtDNA sequencing, and observed crosses between T. fiebrigi males and $T$. angustula females. The authors suggested that the crosses occurred in areas where there was a predominance of $T$. angustula, and $T$. fiebrigi probably produced a greater number of males.

Bayesian analysis in the present study generated similar results as those obtained with the dendrogram, in which it was possible to separate the populations, except for nest 1 from Altônia, which according to the Bayesian analysis was grouped with T. angustula.

For a more robust analysis of the mtDNA fragments, sequencing should be performed in order to obtain sequences that could be compared between the Tetragonisca, and consequently verify the differences at the nucleotide level. In conclusion, we suggest that it would be appropriate to consider T. angustula and T. fiebrigi as two subspecies of $T$. angustula. 


\section{ACKNOWLEDGMENTS}

We thank Coordenação de Aperfeiçoamento de Pessoal de Nível Superior (CAPES) for a scholarship and the Araucária Foundation for financial support.

\section{REFERENCES}

Baitala TV, Mangolin CA, Toledo VAA and Ruvolo-Takasusuki MCC (2006). RAPD polymorphism in Tetragonisca angustula (Hymenoptera; Meliponinae, Trigonini) populations. Sociobiology 48: 861-873.

Barni GS, Strapazzon R, Guerra Jr JCV and Moretto G (2007). Mitochondrial genome differences between the stingless bees Melipona rufiventris and Melipona mondury (Apidae: Meliponini). Genet. Mol. Res. 6: 8-14.

Barth A, Fernandes A, Pompolo SG and Costa MA (2011). Occurrence of B chromosomes in Tetragonisca Latreille, 1811 (Hymenoptera, Apidae, Meliponini): A new contribution to the cytotaxonomy of the genus. Genet. Mol. Biol. 34: 77-79.

Bronzato AR (2011). Amplificação heteróloga e diversidade genética em Tetragonisca angustula (Latreille, 1811) e Tetragonisca fiebrigi (Schwarz, 1938). Master's thesis, UEM, Maringá.

Camargo JMF and Pedro SRM (1992). Systematic, phylogeny and biogeography of the Meliponinae (Hymenoptera: Apoidea): a mini-review. Apidologie 23: 509-522.

Camargo JMF and Pedro SRM (2007). Meliponini Lepeletier, 1836. In: Catalogue of bees (Hymenoptera, Apoidea) in the Neotropical region (Moure JS, Urban D and Melo GAR, eds.). Sociedade Brasileira de Entomologia, Curitiba, 272-578.

Carvalho CAL and Marchini LC (1999). Abundância de ninhos de Meliponinae (Hymenoptera: Apidae) em biótopo urbano no município de Piracicaba-SP. Rev. Agric. 74: 35-44.

Castanheira EB and Contel EBP (1995). Isoenzymes relatedto flight activity in Tetragonisca angustula (Hymenoptera: Apidae: Meliponinae): Evidence of posttranslational modification of the hexokinase and detection of new glycerol-3-phosphate dehydrogenase variants. Biochem. Genet. 33: 365-375.

Castanheira EB and Contel EBP (2005). Geographic variation in Tetragonisca angustula (Hymenoptera, Apidae, Meliponinae). J. Apic. Res. 44: 101-105.

Diniz-Filho JAF, Balestra R, Rodrigues FM and Araújo ED (1998). Geographic variation of Tetragonisca angustula angustula (Hymenoptera: Meliponinae) in Central and Southeastern Brazil. Naturalia 23: 193-208.

Evanno G, Regnaut S and Goudet J (2005). Detecting the number of clusters of individuals using the software STRUCTURE: a simulation study. Mol. Ecol. 14: 2611-2620.

Francisco FO, Santiago LR, Brito RM, Oldroyd BP, et al. (2014).Hybridization and asymmetric introgression between Tetragonisca angustula and Tetragonisca fiebrigi. Apidologie 45: 1-9.

Francisco FO, Silvestre D and Arias MC (2001). Mitochondrial DNA characterization of five species of Plebeia (Apidae: Meliponini): RFLP and restriction map. Apidologie 32: 323-332.

Hall HG and Smith DR (1991). Distinguishing African and European honeybee matrilines using amplified mitochondrial DNA. Proc. Natl. Acad. Sci. U. S. A. 88: 4248-4252.

Kerr WE, Absy ML and Souza ACM (1987). Espécies nectariferas e poliniferas utilizadas pela abelha Melipona compressipes fasciculata (Meliponinae-Apidae) no Maranhão. Acta Amaz. 16-17: 145-156.

Koling DF and Moretto G (2010). Mitochondrial discrimination of stingless bees Tetragonisca angustula (Apidae: Meliponini) from Santa Catarina state, Brazil. Apidologie 41: 454-462.

Menezes-Pedro SR and Camargo JFM (2000). Biodiversidade do estado de São Paulo: síntese do conhecimento ao final do século XX. In: Invertebrados Terrestres (Brandão CR and Cancello EM, eds.). FAPESP, São Paulo, 193-211.

Michener CD (2000). The bees of the world. John Hopkins University Press, Baltimore.

Nei M (1978). Estimation of average heterozigozity and genetic distance from small number of individuals. Genetics 89: 583-590.

Nogueira-Neto P (1997). Vida e criação de abelhas indígenas sem ferrão. Nogueirapis, São Paulo.

Oliveira ML, Morato EF and Garcia MVB (1995). Diversidade de espécies e densidade de ninhos de abelhas sociais sem ferrão (Hymenoptera, Apidae, Meliponinae) em floresta de terra firme na Amazônia Central. Rev. Bras. Zool. 12: 13-24.

Oliveira RC, Nunes FMF, Campos APS, Vasconcelos SM, et al. (2004). Genetic divergence in Tetragonisca angustula Latreille, 1811 (Hymenoptera, Meliponinae, Trigonini) based on RAPD markers. Cell Mol. Biol. 27: 181-186.

Peakall R and Smouse PE (2006). GenAIEx 6.5: genetic analysis in Excel. Population genetic software for teaching and research. Mol. Ecol. Notes 6: 288-295.

Pritchard JK, Stephens M and Donnelly P (2000). Inference of population structure using multilocus genotype data. Genetics 155: 945-959.

Sawaya ACHF, Cunha IBS, Maria C, Marcucci MC, et al. (2006). Brazilian propolis of Tetragonisca angustula and Apis 
mellifera. Apidologie 37: 398-407.

Simon C, Frati F, Bechenbach A, Crespi B, et al. (1994). Evolution, weighting, and phylogenetic utility of mitochondrial gene sequence and compilation of conserved polymerase chain reaction primers. Ann. Entomol. Soc. Am. 87: 651-701.

Stuchi ALBP, Toledo VAA, Lopes DA, Cantagalli LB, et al. (2012).Molecular marker to identify two stingless bee species: Tetragonisca angustula and Tetragonisca fiebrigi (Hymenoptera, Meliponinae). Sociobiology 59: 123-134.

Yeh FC, Yang RC and Boyle T (1999). PopGene version 1.32. Microsoft Windows-Based Freeware for Population Genetic Analysis. University of Alberta, Canada.

Yu KF, Van Deynze A and Paulus KP (1993). Random amplified polymorphic DNA (RAPD) analysis. In: Methods in plant molecular biology andbiotechnology (Glick BR and Thompson JE, eds.). CRC Press, USA, 287-301. 